Thymidine derivatives of this type are uncommon and only recently have thymidine diphosphate rhamnose ${ }^{1}$ and related deoxysugar nucleotides ${ }^{17}$ been described. Guanosine diphosphate mannose ${ }^{18}$ is the only other nucleotide containing mannose. Thymidine diphosphate mannose is of interest as a possible intermediate in the biosynthesis of streptomycin B (a-D-mannopyranosyl-streptomycin) ${ }^{19}$, which occurs together with streptomycin in this micro-organism.

Department of Chemistry, King's College, Unvversity of Durham, J. BADDILEY Nerecastle upon Tyne (Great Britain)

N. L. BLumsom

1 R OKazaki, Brochem. Brophys. Res. Comm., I (I959) 34.

${ }^{2}$ H G. Pontis and N. L. Blumsom, Biochim. Biophys. Acta, 27 (I958) 6 I 8.

3 A C. Paladini and L F Leloir, Biochem. $J$, 5 I (I952) 426.

4 A. Jeanes, C S. Wise and R J. Dimler, Anal Chem., 23 (I95I) 4 I5.

5 S. M Partridge, Biochem $J, 42$ (I948) 238.

6. E Trevelyan, D. P Procter and J S Harrison, Nature, i66 (I950) 444.

${ }^{7}$ E Borenfreund and Z Dische, Arch Biochem Brophys, 67 (I957) 239.

8 R. Consden and W. M Stanier, Nature, I69 (J952) 783 .

9 M Abdel-Akher, J K Hamilton and F Smith, J. Am. Chem. Soc., 73 (I95I) $469 \mathrm{I}$

$10 \mathrm{~J}$. Baddiley, J G, Buchanan and B Carss, $J$. Chem Soc, (1957) $4{ }^{\mathrm{I}} 3^{8}$

11 J. G. Buchanan, Nature, I68 (I95I) IOgI.

12 J. G Buchanan, C A. Dekker and A G Long, J Chem Soc, (1950) 3102

$13 \mathrm{~J}$ Baddiley, J G Buchanan, R E Handschumacher and J F Prescott, $J$ Chem. Soc., $(1956) 2818$

$14 \mathrm{C}$ H Fiske and Y. Subbarow, $J$ Brol Chem, 66 (1925) 375.

$15 \mathrm{~J}$ T. PARK and M. J Johnson, $J$ Biol Chem, i 8 I (1949) 149.

$16 \mathrm{~L}$ A HePpel and R. J Hilmoe, $J$ Biol Chem, i 88 (I95I) 665.

$17 \mathrm{~J}$ L. Strominger and S S ScotT, Brochim Brophys. Acta, 35 (1959) $55^{2}$

13 E Cabib and L F Leloir, $J$ Biol Chem, 206 (I954) 779

$19 \mathrm{H}$ E. Stavely and J Fried, J. Am. Chem. Soc., 7 I (1949) 135.

Receved February 26th, I960

Brochm Brophys Acta, 39 (r960) 376-377

\title{
The isolation of guanosine diphosphate colitose from Escherichia coli
}

The specific immunochemical reactions exhibited by bacterial endotoxins (lipopolysaccharides) are primarily determined by the 3,6-dideoxyhexose components of these substances ${ }^{1}$. LUDERITz et al. ${ }^{2}$ reported that colitose (3,6-dideoxy-L-galactose) is the dideoxyhexose of a lipopolysaccharide solated from Escherichra coli or I I-B. A colitose-contaming nucleotide, guanosine diphosphate colitose, has now been isolated from this organism*.

Cells were grown in a continuous-culture apparatus, harvested durıng exponential growth and washed with water. I kg (wet weight) of cells was extracted with cold Io \% trichloroacetic acıd, the precipitate removed by centrifugation and the supernatant fluid extracted 5 times with ice-cold ether. The ultraviolet-absorbing material in the neutral extract was fractionated on Dowex-I ( $\mathrm{Cl}^{-}$form) resın using $\mathrm{LiCl}$ as

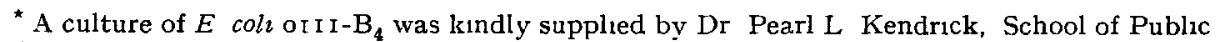
Health, University of Michigan, Ann Arbor, Mich 
the eluting agent. The crude nucleotide fraction, eluted with $0.25 M$ to $0.35 M \mathrm{LiCl}$, was concentrated and the lithium salts of the nucleotides were precipitated. Analysis of a portion of this fraction, after hydrolysis at $100^{\circ}$ in $0.01 \mathrm{~N} \mathrm{HCl}$ for Io min, indicated the presence of colitose as determined by paper chromatography and the reaction obtained with 2 -thiobarbituric $a \mathrm{cid}^{*}$. No other reducing substances were detected on the chromatograms with the ammoniacal $\mathrm{AgNO}_{3}$ reagent ${ }^{4}$. Colitose was not detected in the crude nucleotide fraction prior to acid hydrolysis Further fractionation of the crude lithium salts by treatment with charcoal, paper chromatography and paper ionophoresis yielded $2.5 \mu$ moles of a colitose-contaning nucleotide Paper chromatography in two solvent systems and ionophoresis** indicated that the substance was homogeneous; in each case, hydrolysis of the ultraviolet-absorbing spot yielded colitose The ultraviolet-absorption spectrum of the nucleotide was identical with that of guanosine monophosphate at $\mathrm{pH}$ 's I.0, 7.0 and II.O. Analysis of the material indicated the following molar ratios. guanine, r.o; organic phosphorus, I 97 ; colitose, 0.95 . The colitose morety was further characterized, following hydrolysis of the nucleotide, by comparison with authentic colitose ${ }^{\star \star \star}$ in three paper-chromatographic solvent systems. Similarly, the only ultraviolet-absorbing material present in such an hydrolysate was chromatographically indistinguishable from guanosine diphosphate ${ }^{5}$. The nucleotide exhibited a negative reaction with diphenylamine although deoxyguanosine monophosphate gave a typical blue color under the same conditions. The nucleotide apparently is guanosine diphosphate colitose.

The occurrence of a guanosine nucleotide containing colitose suggests a possible metabolic relationship to the other known guanosine sugar nucleotides such as guanosine diphosphate mannose and guanosine diphosphate fucose, the relationship between the latter compounds already has been demonstrated ${ }^{6}$

The Rackham Arthritss Research Unit is supported by a grant from the Horace H. Rackham School of Graduate Studies of the University of Michigan. This investigation was aided by a grant from the National Institutes of Health (A-2963).

\section{Rackham Arthrtis Research Unt and Department of Bacternology, EDWARD C. HEATH The University of Michigan, Ann Avbor, Mich. (U.S A.)}

1 A M Staub, R. Tinelli, O Luderitz and O Westphal, Ann. 2 nst Pasteur, 96 (I959) 303

2 O Luderitz, A. M Staub, S Stirm and O Westphal, Brochem $Z, 330$ (1958) r93

3 V. S Waravdekar and L. D Saslaw, J Biol Chem., 234 (I959) I945

4 W. E Trevelyan, D. P Procter and J S Harrison, Nature, i66 (I95o) 444.

5 R M Bock, N S Ling, S A Morell and S H Lipton, Arch Brochem. Bıophy's, 62 (I956) 253.

${ }^{6} \mathrm{~V}$ Ginsburg, $J$. Am Chem Soc, 8o (1958) 4426 .

Received February 20th, 1960

* Oxidation of colitose with periodic acid yields malonyl dialdehyde which reacts with 2-thiobarbituric acid to give a pink-colored complex absorbing maximally at $532 \mathrm{~m} \mu$ (ref 3 )

* Chromatography of sugars was carried out on Whatman No I paper in the following solvent systems · (a) butanol (6)-pyridine (4)-water (3), (b) ethyl acetate (3)-acetic acid (I)-water (3), (c) butanol (IO)-ethanol (I) - water (2). Paper 1onophoresis was carried out on Whatman No $3 \mathbf{M M}$ paper at $10 \mathrm{~V} / \mathrm{cm}$ in $005 M$ phosphate buffer, $\mathrm{pH} 74$

** We are grateful to Dr A M Staub, L'Institut Pasteur, Paris, for immunochemically authent1cating our preparation of colitose A sample of synthetic colitose was kindly supplied by Dr. O Westphal, Dr A Wander Forschungsinstitut, Freiburg-Zahrıngen, Germany 